\title{
EFFECT OF CRYOGENIC TREATMENT APPLIED TO M42 HSS DRILLS ON THE MACHINABILITY OF Ti-6Al-4V ALLOY
}

\author{
VPLIV PODHLAJEVANJA SVEDROV M42 HSS NA \\ OBDELOVALNOST ZLITINE Ti-6Al-4V
}

\author{
Turgay Kıvak ${ }^{1}$, Ulvi Şeker ${ }^{2}$ \\ ${ }^{1}$ Düzce University, Faculty of Technology, Department of Manufacturing Engineering, Düzce, Turkey \\ ${ }^{2}$ Gazi University, Faculty of Technology, Department of Manufacturing Engineering, Ankara, Turkey \\ turgaykivak@duzce.edu.tr \\ Prejem rokopisa - received: 2014-11-16; sprejem za objavo - accepted for publication: 2014-12-16
}

doi:10.17222/mit.2014.283

\begin{abstract}
This study investigated the effects of deep cryogenic treatment applied to M42 HSS drills on the tool wear, the tool life and the surface roughness during the drilling of a Ti-6Al-4V alloy under dry and wet cutting conditions. Drilling tests were carried out using untreated, cryogenically treated, cryogenically treated and tempered, and multi-layered TiAlN/TiN-coated HSS drills. Four different cutting speeds $((6,8,10,12) \mathrm{m} / \mathrm{min})$ and a constant feed rate of $0.06 \mathrm{~mm} / \mathrm{r}$ were used as the cutting parameters and holes with a depth of $15 \mathrm{~mm}$ were drilled. At the end of the drilling tests, it was seen that the use of a coolant increased the tool life and decreased the surface roughness. Among the four tools, the best results in terms of the tool life and surface roughness were obtained with the multi-layered TiAlN/TiN-coated tool. The cryogenically treated and tempered drills exhibited an increase of $87 \%$ in the tool life compared to the untreated drills. Scanning electron microscope (SEM) and X-ray diffraction (XRD) analyses showed that by reducing the size of the carbide particles in the microstructure, cryogenic treatment resulted in a more uniform carbide distribution and in the transformation of retained austenite to martensite. This played an important role in the increase in the hardness and wear resistance of the cutting tools.

Keywords: cryogenic treatment, microstructure, M42 HSS, drilling, tool life, surface roughness
\end{abstract}

V tej študiji je bil preiskovan vpliv globokega podhlajevanja svedrov M42 HSS na njihovo obrabo, zdržljivost in hrapavost površine med suhim in mokrim vrtanjem zlitine Ti-6Al-4V. Preizkusi vrtanja so bili izvršeni z uporabo HSS neobdelanih, podhlajenih, podhlajenih in popuščanih ter svedrov z večplastnim nanosom TiAlN/TiN. Uporabljene so bile štiri različne hitrosti rezanja $((6,8,10,12) \mathrm{m} / \mathrm{min})$ in konstantno podajanje $0,06 \mathrm{~mm} / \mathrm{r}$ pri vrtanju $15 \mathrm{~mm}$ globokih izvrtin. Na koncu preizkusov vrtanja se je pokazalo, da uporaba hlajenja s tekočino poveča zdržljivost orodja in zmanjša hrapavost površine. Med štirimi orodji je bil glede na njihovo zdržljivost in hrapavost površine najboljši rezultat dosežen z orodji z večplastnim nanosom TiAlN/TiN. Podhlajeni in popuščani svedri so imeli povečano zdržljivost za $87 \%$ v primerjavi z neobdelanimi svedri. Analize na vrstičnem elektronskem mikroskopu (SEM) in rentgenska difrakcija (XRD) sta pokazali, da z zmanjšanjem velikosti karbidnih zrn v mikrostrukturi pri podhlajevanju dobimo bolj enakomerno razporeditev karbidov, preostali avstenit pa se pretvori v martenzit. To ima pomembno vlogo pri povečanju trdote in odpornosti orodja za rezanje proti obrabi.

Ključne besede: obdelava s podhlajevanjem, mikrostruktura, M42 HSS, vrtanje, zdržljivost orodja, hrapavost površine

\section{INTRODUCTION}

With the rapid development of technology, the past few years have witnessed a rise in the expectations for the products made of resistant, lightweight materials and their production methods. In particular, the need for such materials in the electronics, computer, automotive and aerospace industries is increasing. Titanium and its alloys meet a great many of these expectations due to their low density, high resistance, and heat and corrosion resistance. ${ }^{1-3}$ Among these alloys, all having different properties, Ti-6Al-4V is the most widely used and it is found in $60 \%$ of industrial applications. This alloy has the properties of high resistance to fatigue and corrosion along with high strength and biocompatibility, and covers a wide application field, primarily in the aerospace industry. ${ }^{4}$ However, the Ti-6Al-4V alloy belongs to a group of materials which are difficult to machine because of their high chemical reactivity and high tendency to weld to the cutting tool, ${ }^{5}$ low heat conductivity, maintenance of strength at high temperatures and a low elasti- city module. Furthermore, the production cost of these materials is high and errors during machining can cause serious increases in the cost of machining. ${ }^{6-10}$

The life of cutting tools plays a major role in increasing the productivity and, consequently, it is an important economic factor. In order to increase the life of cutting tools, a common approach in the past was to heat-treat the tool materials, thus providing a greater control over the range of the properties that a given tool material might have. In order to increase the life of cutting tools and improve their properties, the conventional heat treatment, applied especially to tool steel and high-speed steel (HSS), has been a widely used method for many years. ${ }^{11}$ Cryogenic treatment is generally a complementary treatment to the heat treatment applied to increase the wear resistance of the materials exposed to high wear conditions. It is also known as the cold or subzero treatment. ${ }^{12}$ It is cheap and permanent; it is done once and, unlike coatings, it affects the whole piece. ${ }^{13}$ Cryogenic treatment, depending on the temperatures 
applied to the material, is classified as shallow cryogenic treatment (between $-50{ }^{\circ} \mathrm{C}$ and $-100{ }^{\circ} \mathrm{C}$ ) and deep cryogenic treatment (lower than $-125^{\circ} \mathrm{C}$ ).

After the conventional heat treatment, materials are first held at the temperatures of shallow or deep cryogenic treatment (generally for $24 \mathrm{~h}$ ) and then brought gradually up to room temperature. ${ }^{14}$ In this way, the formation of fine carbide precipitates, a uniform carbide distribution and a conversion of the retained austenite to martensite are achieved. Thus, significant improvements are obtained in the mechanical properties of the materials such as the hardness and wear resistance. ${ }^{15-17}$ Cryogenic treatment, having been previously applied to tool/die steels, is now applied to the cutting tools in the machining and, as a result, important developments have been obtained in the tool wear, tool life and recovery of cutting conditions. Studies on cryogenically treated high-speed-steel tools show microstructural changes in the material that can considerably influence the tool life and productivity. In the literature, results showed tool-life improvements ranging from $92 \%$ to $817 \%$ for the cryogenically treated HSS tools in the industrial use. ${ }^{13}$

The influence of deep cryogenic treatment on the wear resistance and the tool life of M42 HSS drills with a high-speed dry-drilling configuration of carbon steels was studied and the experimental results indicated toollife improvements of $77 \%$ and $126 \%$ for cryogenically treated and cryogenically treated + tempered drills, respectively. ${ }^{16}$ The improvement in the wear resistance and the significance of the treatment parameters for different materials were investigated in another study. It was found that cryogenic treatment provided an improvement in the tool life of nearly $110 \%$. The tool-life improvement was even higher with the use of TiN coatings. ${ }^{18}$

Compared to the other material-removal processes, the drilling process has quite a wide application field. Especially in the aerospace industry, drilling constitutes a large portion of the material-removal processes, up to 40-60 \%. ${ }^{19}$ In the literature, studies investigating the machinability of titanium alloys are generally focused on turning and milling while those dealing with drilling are very limited.

In this study, cryogenic-treatment-induced changes in the microhardness and microstructure of M42 HSS tools and the effects of these changes on the tool wear, tool
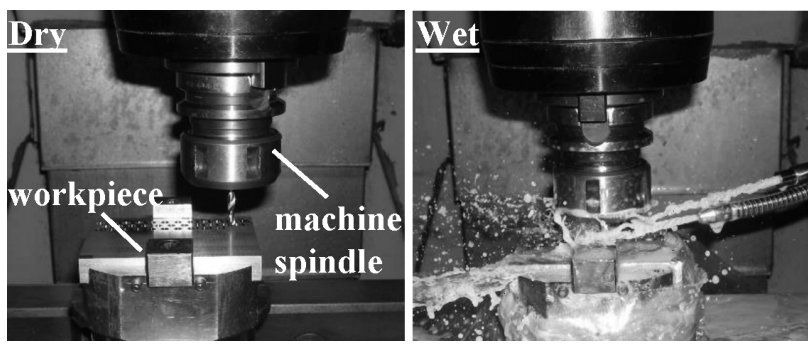

Figure 1: Details of the experimental set-up

Slika 1: Podrobnosti eksperimentalnega sestava life and surface roughness during the drilling of a Ti-6Al-4V alloy were investigated. Furthermore, the machining performance of cryogenically treated tools was examined in comparison with that of the untreated and multi-layered TiAlN/TiN-coated tools.

\section{EXPERIMENTAL METHODS}

\subsection{Drilling experiments}

Drilling tests were carried out using a JOHNFORD VMC 550-7.5 kW CNC vertical machining center under dry and wet cutting conditions. Four different cutting speeds $(6,8,10$ and 12) $\mathrm{m} / \mathrm{min}$ were used for the experiments and the hole depth and feed rate were kept constant at $15 \mathrm{~mm}$ and $0.06 \mathrm{~mm} / \mathrm{r}$, respectively. The experimental set-up is shown in Figure 1. For the workpiece material, $100 \mathrm{~mm} \times 80 \mathrm{~mm} \times 15 \mathrm{~mm}$ blocks of the Ti-6Al-4V alloy were used. Before the experiments, the sample blocks were ground to eliminate the adverse effects of any surface defects. The chemical composition and mechanical properties of the workpiece material are shown in Tables $\mathbf{1}$ and $\mathbf{2}$, respectively.

Table 1: Chemical composition of Ti-6Al-4V alloy (w/\%)

Tabela 1: Kemijska sestava zlitine Ti-6Al-4V (w/\%)

\begin{tabular}{|c|c|c|c|c|c|c|c|}
\hline $\mathrm{Ti}$ & $\mathrm{Al}$ & $\mathrm{V}$ & $\mathrm{Fe}$ & $\mathrm{O}$ & $\mathrm{C}$ & $\mathrm{N}$ & $\mathrm{H}$ \\
\hline 89.85 & 5.90 & 4.00 & 0.08 & 0.14 & 0.01 & 0.01 & 0.002 \\
\hline
\end{tabular}

Table 2: Mechanical properties of Ti-6Al-4V

Tabela 2: Mehanske lastnosti zlitine Ti-6Al-4V

\begin{tabular}{|c|c|c|c|}
\hline $\begin{array}{c}\text { Tensile } \\
\text { strength }(\mathrm{MPa})\end{array}$ & $\begin{array}{c}\text { Yield strength } \\
(\mathrm{MPa})\end{array}$ & $\begin{array}{c}\text { Elongation 5D } \\
(\%)\end{array}$ & Hardness $\left(R_{\mathrm{c}}\right)$ \\
\hline $900-1100$ & 830 & 10 & 36 \\
\hline
\end{tabular}

In the wet cutting experiments, a $6 \%$ concentration of a semi-synthetic emulsion was used as the coolant. For the elimination of the twisting effect, the distance from the tool holder to the drill tip was determined as 30 $\mathrm{mm}$. This value was kept constant in all the experiments in order to validate the obtained values. Three holes were drilled under each machining condition for the comparison of the surface-roughness measurements. The average of each set of three measurements was used for the comparison. As the initial condition of each test, a new drill was used for each experiment. The surface roughness of the machined holes was measured using a Mohr Perthometer M1 portable surface-roughness tester for each machining condition and the average values of the surface roughness $\left(R_{\mathrm{a}}\right)$ were determined. In order to measure the surface roughness, the Ti-6Al-4V alloy blocks were sliced parallel to the hole axes and the measurements were taken at three different points. The average of these three measurements was used in the evaluations.

For the tool-wear experiments, as various wear mechanisms and types were formed on the drills and the 
cost of the workpiece was high, the following were determined as the tool-life criteria: ${ }^{20}$

- the average non-uniform flank wear $V_{\mathrm{b}}=0.15 \mathrm{~mm}$

- the maximum flank wear $V_{\mathrm{bmax}}=0.2 \mathrm{~mm}$

- the chipping $=0.2 \mathrm{~mm}$

- the out-of-corner wear $=0.2 \mathrm{~mm}$

- the fracture or catastrophic failure

As soon as one of the criteria mentioned above was realized, it was accepted that the tool was worn. A professional hand-held digital microscope (Dino-Lite, AM413ZT) and a JEOL JSM-6060 LV scanning electron microscope (SEM) were used to determine the wear mechanisms and types. Due to the limited amount and high cost of the workpiece material, the tool wear experiments were performed only at the cutting speed of $10 \mathrm{~m} / \mathrm{min}$. The tool life time was obtained by multiplying the total number of holes drilled by the drilling time at which the tool reached one of the wear criteria.

\subsection{Cryogenic treatment and tempering}

A number of uncoated and coated drills (Guhring) of a $5 \mathrm{~mm}$ diameter were cryogenically treated in order to observe the effect of cryogenic treatment on the drilling of the Ti-6Al-4V alloy with M42 HSS twist drills. Three types of uncoated drills were used: untreated drills (U), cryogenically treated drills (CT), and cryogenically treated and tempered (at $200{ }^{\circ} \mathrm{C}$ for $2 \mathrm{~h}$ ) drills (CTT). Cryogenic treatment was not applied to the TiAlN/TiNcoated drills in order to compare the performance of the cryogenically treated material to that of the coated material. The chemical composition and properties of the M42 HSS twist drills used in the experiments are given in Tables $\mathbf{3}$ and $\mathbf{4}$, respectively.

Table 3: Chemical composition of M42 HSS drills (w/\%) Tabela 3: Kemijska sestava svedrov M42 HSS (w/\%)

\begin{tabular}{|c|c|c|c|c|c|}
\hline $\mathrm{C}$ & $\mathrm{Cr}$ & $\mathrm{Co}$ & Mo & W & V \\
\hline 1.1 & 4.2 & 8.0 & 10 & 1.8 & 1.2 \\
\hline
\end{tabular}

Table 4: Properties of M42 HSS drills

Tabela 4: Lastnosti svedrov M42 HSS

\begin{tabular}{|c|c|c|}
\hline & $\begin{array}{c}\text { Uncoated HSS } \\
(\text { U, CT, CTT) }\end{array}$ & Coated HSS (U) \\
\hline Tool material & M42 & M42 \\
\hline Tool reference & DIN 338 & DIN 338 \\
\hline Point angle & $135^{\circ}$ & $35^{\circ}$ \\
\hline Helix angle & $35^{\circ}$ & $5 \mathrm{~mm}$ \\
\hline Diameter & $5 \mathrm{~mm}$ & Multi-layer TiAlN/TiN \\
\hline Coating & - & $4 \mu \mathrm{m}$ \\
\hline Coating thickness & - & $3600\left(\mathrm{HV}_{0.05}\right)$ \\
\hline Hardness & - & \\
\hline
\end{tabular}

The cryogenic treatment of the M42 HSS drills was performed by gradually lowering the temperature from room temperature to $-145{ }^{\circ} \mathrm{C}$ at the cooling rate of about $1-2{ }^{\circ} \mathrm{C} / \mathrm{min}$, holding the drills at this cryogenic temperature for $24 \mathrm{~h}$, and then raising the temperature back to

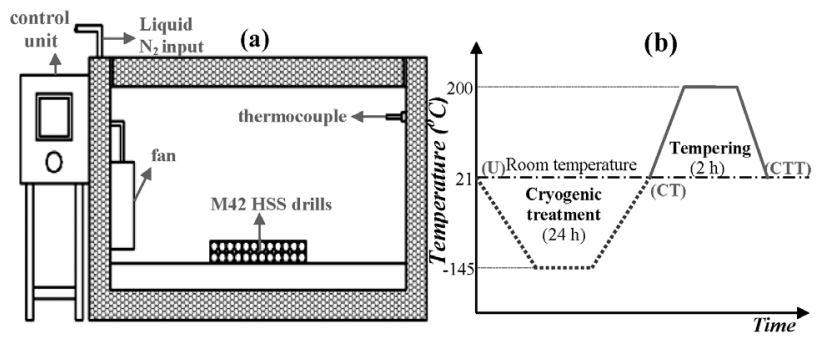

Figure 2: Details of the cryogenic-treatment process: a) schematic configuration of the cryogenic-treatment system, b) cryogenic treatment and tempering cycle used for M42 HSS drills

Slika 2: Podrobnosti postopka podhlajevanja: a) shematski prikaz sistema za podhlajevanje, b) cikel podhlajevanja in popuščanja, uporabljenega pri svedrih M42 HSS

room temperature at the heating rate of $1-2{ }^{\circ} \mathrm{C} / \mathrm{min}$. Figure 2 schematically illustrates the cryogenic treatment applied to the M42 HSS drills. To verify the formation of fine and homogeneous carbide particles and the transformation of the retained austenite to martensite, the microstructures of the untreated, cryogenically treated, and cryogenically treated and $2 \mathrm{~h}$ tempered drills were observed via SEM photographs and X-ray diffraction (XRD) profiles. The microstructure and phase distribution were characterized with SEM and the volume fraction of the retained austenite was determined using a GE-SEIFERT X-ray diffraction instrument with a $\mathrm{Cr}-K \alpha_{1}$ $\mathrm{X}$-ray source. From the X-ray diffractograms, the contents of the retained austenite and martensite in the alloy after different treatments were measured using the ASTM E975-84 standard. $^{21}$

\section{RESULTS AND DISCUSSION}

\subsection{Evaluation of cryogenic treatment of drills}

In the HSS tools the main alloying elements which change the microstructure and the properties are $\mathrm{C}, \mathrm{Cr}$, Mo, V, W and Co. Except for Co, these elements precipitate in the microstructure and create carbides. Generally, seven groups of carbides precipitate in high-speed steels: (1) E carbide, $\mathrm{Fe}_{2.4} \mathrm{C}$ (hcp); (2) $\theta$-carbide, $\mathrm{M}_{3} \mathrm{C}\left(\mathrm{Fe}_{3} \mathrm{C}\right)$; (3) $\mathrm{MC}$ or $\mathrm{M}_{4} \mathrm{C}_{3},\left(\mathrm{~V}_{4} \mathrm{C}_{3}\right)$; (4) $\mathrm{M}_{2} \mathrm{C},\left(\mathrm{W}_{2} \mathrm{C}\right.$ or $\left.\mathrm{Mo}_{2} \mathrm{C}\right)$; (5) $\lambda$-carbide, $\mathrm{M}_{7} \mathrm{C}_{3}\left(\mathrm{Cr}_{7} \mathrm{C}_{3}\right)$; (6) $\gamma$-carbide, $\mathrm{M}_{23} \mathrm{C}_{6}\left(\mathrm{Cr}_{23} \mathrm{C}_{6}\right)$; (7) $\eta$-carbide, $\mathrm{M}_{6} \mathrm{C}\left(\mathrm{Fe}_{3} \mathrm{~W}_{3} \mathrm{C}\right.$ or $\left.\mathrm{Fe}_{4} \mathrm{~W}_{2} \mathrm{C}\right)$, as expressed $i^{22}$. The $\mathrm{M}_{6} \mathrm{C}$ carbides were originally known as high-speed steels and they are similar to the complex surface-centered cubical carbides that are rich in tungsten and molybdenum and give red hardness to steel. The distribution of these carbide particles in the microstructure, their size, their amount and the distances between them affect the mechanical properties of the material. ${ }^{23}$

In this study, profiles were obtained from the XRD analyses. These analyses were made to determine the differences in the amount of the carbide present in the cryo-treated (CT) and cryo-treated and tempered (CTT) drills compared to the untreated (U) tool (Figure 3). For the purpose of determining the residual-austenite vol- 

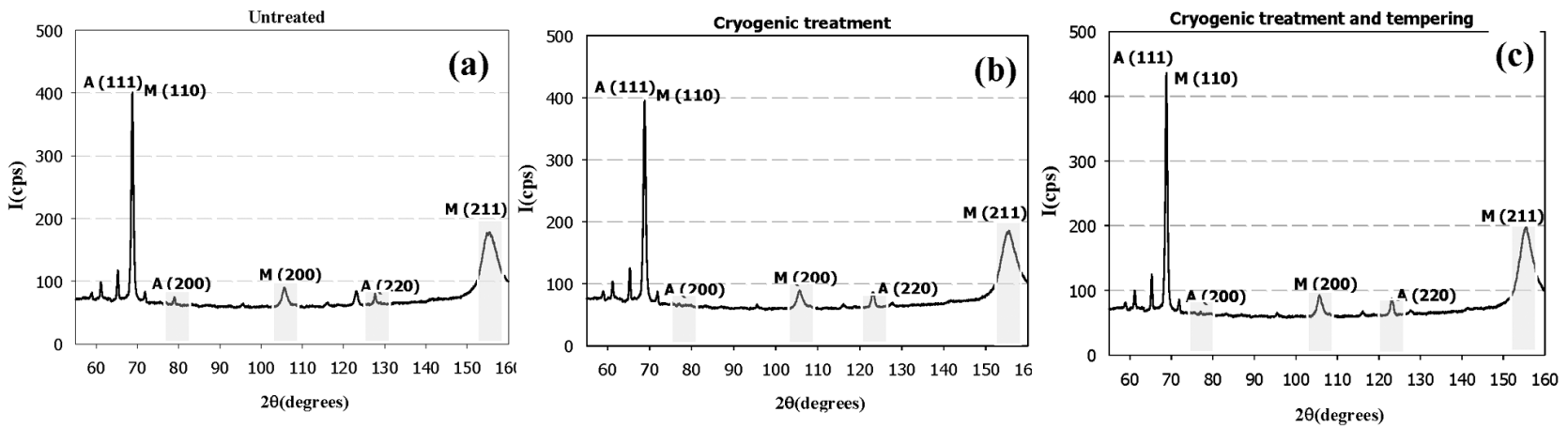

Figure 3: XRD profiles of HSS tools: a) untreated, b) cryo-treated, c) cryo-treated and tempered Slika 3: Rentgenogram HSS-orodij: a) neobdelano, b) podhlajeno, c) podhlajeno in popuščano

ume, the peaks in the austenite (A200 and A220) and martensite (M200 and M211) planes were used. With the cryogenic treatment and cryogenic treatment + tempering, the austenite peaks in the A200 and A220 planes decreased, while the martensite peaks in the M200 and M211 planes increased. The volume proportion of the retained austenite in the untreated tool was measured as $6.5 \%$ and in the cryo-treated and cryo-treated + tempered tools this proportion was $2.4 \%$ and $1.8 \%$, respectively. Therefore, the cryogenic and tempering treatments played an important role in the transformation of the austenite (retained in the structure after the conventional heat treatment) into martensite. It is believed that the transformation of the retained austenite into martensite due to cryogenic treatment can provide significant improvements in the mechanical properties of cutting tools such as hardness. This was verified with the positive variations that occurred in the hardness and the microstructure.

After the cryogenic treatment, a Leica WMHT MOT microhardness tester was used to measure the Vickers HV microhardness on one cryogenically treated sample, one cryogenically treated and $2 \mathrm{~h}$ tempered sample and one untreated sample, with a minimum of eight indentations in each sample and the average used for the comparison. In Table 5, the differences in the microhardness values depending on the treatment applied to the M42 HSS tools are seen. On the untreated tool, the initial hardness was $703 \mathrm{HV}$ and immediately after the cryo- genic treatment it became $742 \mathrm{HV}$. After the cryogenic treatment, tempering was applied and the hardness was measured as $718 \mathrm{HV}$. With the cryogenic treatment and cryogenic treatment + tempering the percentages of the increase in the hardness were 5.5 and 2.1, respectively. It is thought that the increase in the hardness after the cryogenic treatment is the result of the transformation of the austenite retained after the conventional heat treatment to martensite. ${ }^{15,24}$ Moreover, the influence of cryogenic treatment on the increasing hardness can be found in the literature as well. ${ }^{13,25,26}$ Although hardness values differ depending on the material type and application method, increases in the hardness values of 1-3 HRC can be obtained with the cryogenic treatment. ${ }^{16}$ The tempering treatment caused some decrease in the hardness compared to the cryogenic treatment; however, it was observed that the hardness value was still higher than that of the untreated tool. It was assumed that this decrease in the hardness was the result of the dissociation

Table 5: Microhardness and retained-austenite volume after different treatment cycles

Tabela 5: Mikrotrdota in volumen zaostalega avstenita po različnih ciklih obdelave

\begin{tabular}{|c|c|c|}
\hline Cutting tools & $\begin{array}{c}\text { Retained austenite } \\
(\varphi / \%)\end{array}$ & $\begin{array}{c}\text { Microhardness } \\
\left(\mathrm{HV}_{0.2}\right)\end{array}$ \\
\hline Untreated & 6.5 & 703 \\
\hline Cryo-treated & 2.4 & 742 \\
\hline $\begin{array}{c}\text { Cryo-treated and } \\
\text { tempered }\end{array}$ & 1.8 & 718 \\
\hline
\end{tabular}
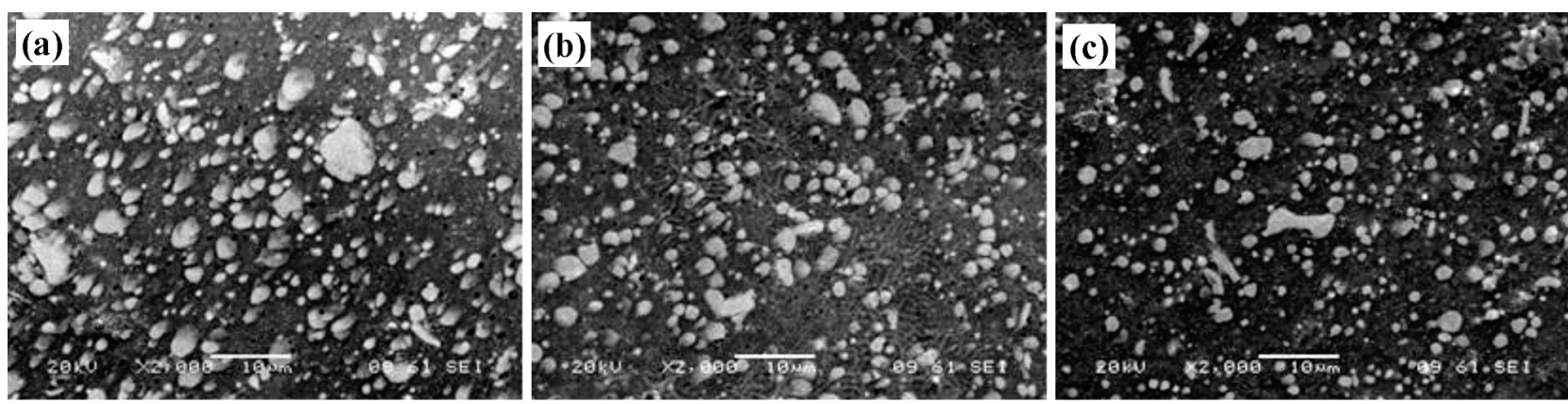

Figure 4: Microstructures of the drills: a) untreated, b) cryo-treated, c) cryo-treated and tempered Slika 4: Mikrostruktura svedrov: a) neobdelano, b) podhlajeno, c) podhlajeno in popuščano 
of some $\mathrm{MC}(\mathrm{Mo}, \mathrm{V}, \mathrm{W}, \mathrm{Cr})$ carbides and precipitate phases.

In order to specify the changes in the microstructure caused by the cryogenic treatment and cryogenic treatment + tempering applied to the HSS tools compared to the untreated tools, SEM microstructure photographs were taken. The purpose of the microstructure examination was to explain the increasing hardness values and the improved tool life. The cutting-tool performance depends on the carbide properties in the microstructure. The microstructures of the U, CT and CTT HSS tools are shown in Figure 4. From the photograph of the untreated HSS-tool microstructure (Figure 4a), it is clear that the carbide particles in the matrix are large. As a result of the cryogenic treatment and cryogenic treatment and tempering, the carbide particles decreased in size and exhibited a much better distribution (Figures $\mathbf{4 b}$ and $\mathbf{4 c}$ ). Cryogenic treatment and tempering may cause a further increase in the particle volume fraction. Compared with Figures $\mathbf{4 a}$ and $\mathbf{4 b}$, in Figure $\mathbf{4 c}$, it is possible to see a decrease in the size of the particles and a more uniform distribution of these particles due to the dissolution of the precipitates and the fracture of large particles.

With the decrease in the size of the carbide particles and their uniform distribution, the interior stresses in the martensite structure are relieved and the micro-cracking sensitivity is minimized, thus providing a significant improvement in the hardness and wear resistance. The precipitation of fine carbides as a result of cryogenic treatment is responsible for the improvement in the wear resistance. ${ }^{15}$ The increase in the microhardness as a result of cryogenic treatment seems to confirm this thesis. Uygur ${ }^{27}$ showed that there was a strong relationship between the microstructure hardness and the wear properties of steel. Cryogenic treatment provides not only a carbide formation but also a uniform carbide distribution. ${ }^{15,16}$ The tempering after the cryogenic treatment provides the second carbide precipitation and plays an effective role in relieving interior stresses. ${ }^{16}$ Thus, in this study, it was thought that non-uniform

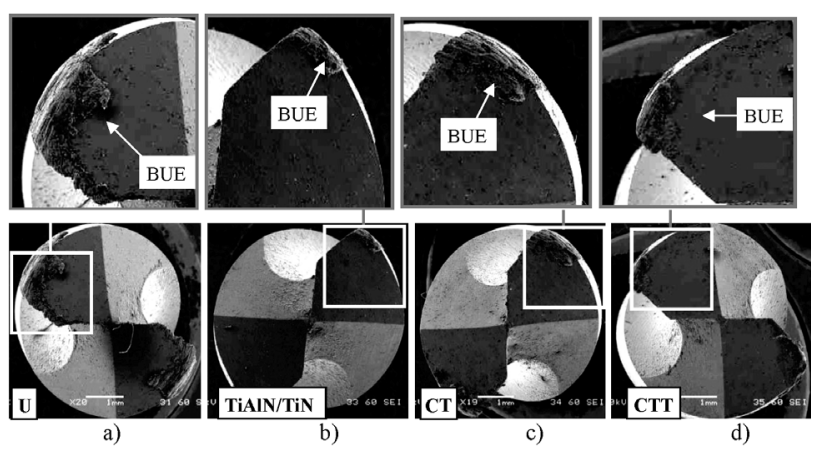

Figure 5: SEM images of drills tested under dry cutting conditions, at $10 \mathrm{~m} / \mathrm{min}$ cutting speed and $0.06 \mathrm{~mm} / \mathrm{r}$ feed rate: a) U, b) TiAlN/TiN, c) CT, d) CTT

Slika 5: SEM-posnetki svedrov, preizkušenih v suhih razmerah, hitrost rezanja $10 \mathrm{~m} / \mathrm{min}$ in hitrost podajanja $0,06 \mathrm{~mm} / \mathrm{r}$ : a) $\mathrm{U}$, b) TiAlN/TiN, c) CT, d) CTT carbides of different sizes were subjected to a size reduction by the cryogenic treatment, and then the tempering relieved the interior stresses.

\subsection{Evaluation of the tool wear}

A series of wear experiments was carried out in order to compare the performances of the U, TiAlN/TiNcoated, CT and CTT tools under dry and wet cutting conditions. In the wear experiments, holes with a depth of $15 \mathrm{~mm}$ were drilled at a cutting speed of $10 \mathrm{~m} / \mathrm{min}$ and a feed rate of $0.06 \mathrm{~mm} / \mathrm{r}$. Under dry cutting conditions, the wear curve could not be obtained because the tool was subjected to a catastrophic failure due to an excessive adhesion without showing a regular wear tendency. Figure 5 shows SEM images of the four different tools tested under dry cutting conditions. It was clearly observed that the high temperatures generated at the cutting area due to a lower coefficient of the heat conductivity of titanium in all of the drills caused a built-up edge (BUE). ${ }^{28}$ Another BUE formation was observed at the outer corners, in particular where the cutting speed was at its maximum. This was because the outer-corner area was subjected to the extensive heat and chemical loads due to a greater heat generation. The adhesion tendency was higher with the untreated tool although fewer holes were drilled with it (Figure 5a). At the specified cutting parameters, the uncoated (U) tool completed its life after the drilling of four holes, the CT tool completed it after five holes, the CTT tool after six holes and the TiAlN/TiN-coated tool after seven holes. It was observed that the lower heat conductivity and friction coefficient of the coating reduced the friction at the tool-chip interface and decreased the BUE formation.

Under wet-cutting conditions, a more regular wear tendency was observed compared to dry cutting condi-

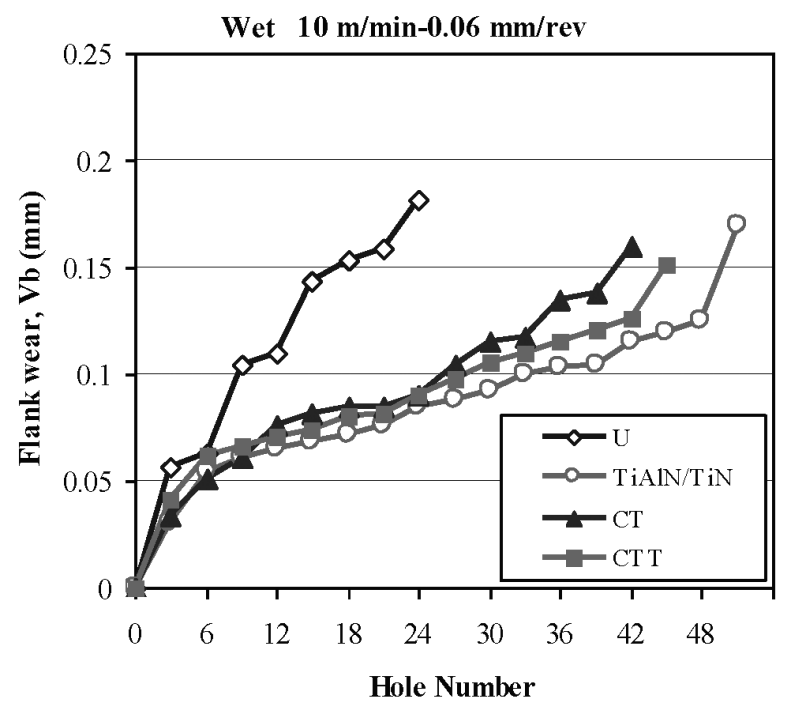

Figure 6: Number of holes and flank wear for drills under wet cutting conditions, at $10 \mathrm{~m} / \mathrm{min}$ cutting speed and $0.06 \mathrm{~mm} / \mathrm{r}$ feed rate

Slika 6: Število lukenj in obraba bokov pri svedrih v mokrih razmerah rezanja: hitrost rezanja $10 \mathrm{~m} / \mathrm{min}$, hitrost podajanja $0,06 \mathrm{~mm} / \mathrm{r}$ 


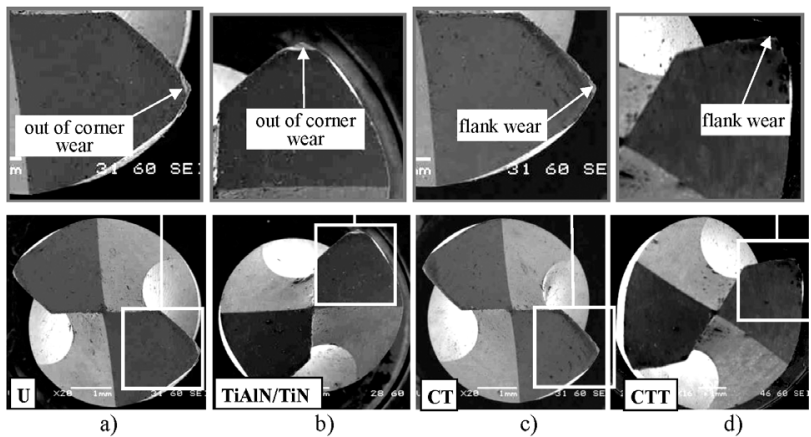

Figure 7: SEM images of drills tested under wet cutting conditions, at $10 \mathrm{~m} / \mathrm{min}$ cutting speed and $0.06 \mathrm{~mm} / \mathrm{r}$ feed rate: a) $\mathrm{U}$, b) TiAlN/TiN, c) CT, d) CTT

Slika 7: SEM-posnetki svedrov, preizkušenih pri mokrem rezanju: hitrost rezanja $10 \mathrm{~m} / \mathrm{min}$ in hitrost podajanja $0,06 \mathrm{~mm} / \mathrm{r}$ : a) $\mathrm{U}$, b) TiAlN/TiN, c) CT, d) CTT

tions, and with the specified tool-wear criteria, the flank-wear curve was obtained, depending on the number of holes. In Figure 6, under wet cutting conditions, the differences in the number of holes and flank wear among the four different tools, at the cutting speed of 10 $\mathrm{m} / \mathrm{min}$ and the feed rate of $0.06 \mathrm{~mm} / \mathrm{r}$, are given. The best performance in terms of the tool wear was obtained with the multi-layered TiAlN/TiN-coated tool, followed by the CTT, CT, and $\mathrm{U}$ tools, respectively. The $\mathrm{U}$ tool reached a flank wear value of $0.15 \mathrm{~mm}$ at the $24^{\text {th }}$ hole, the CT tool at the $42^{\text {nd }}$ hole, the CTT tool at the $44^{\text {th }}$ hole, and the TiAlN/TiN-coated tool at the $51^{\text {st }}$ hole. At this stage it is possible to state that cryogenic and tempering treatments created a change in the microstructure and provided an increase in the hardness, which had an important influence on the tool life. In general, while the TiAlN/TiN-coated, CT and CTT tools exhibited similar flank-wear values up to the $27^{\text {th }}$ hole, after this hole, a wear difference began to be seen. In particular, the CT and CTT tools reached the tool wear criterion with a difference of a couple of holes.

In Figure 7, SEM images of the four different cutting tools tested under wet-cutting conditions are shown.

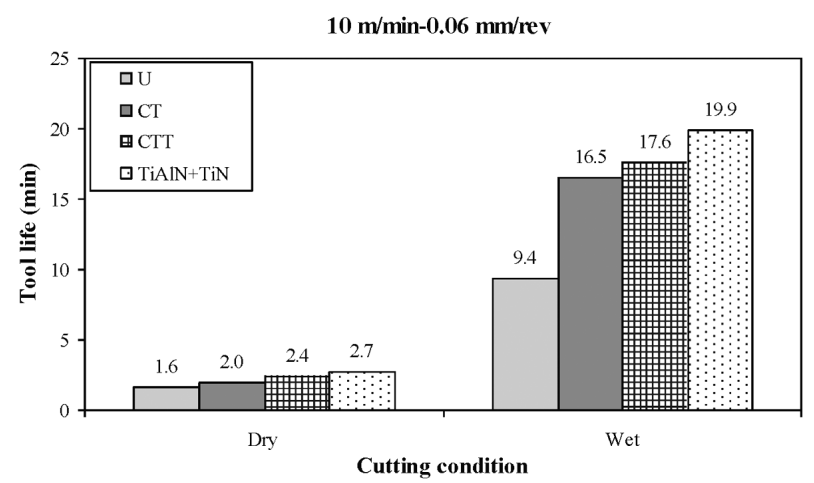

Figure 8: Tool-life differences depending on cutting conditions for the four tools at $10 \mathrm{~m} / \mathrm{min}$ cutting speed and $0.06 \mathrm{~mm} / \mathrm{r}$ feed rate

Slika 8: Razlike v zdržljivosti orodja v odvisnosti od razmer pri rezanju pri štirih orodjih pri hitrosti rezanja $10 \mathrm{~m} / \mathrm{min}$ in hitrosti podajanja $0,06 \mathrm{~mm} / \mathrm{r}$
From these images it can be seen that here the tool wear is more regular in comparison with the dry cutting conditions. The tendency to form an excessive BUE formation that was observed with dry cutting conditions was minimized with the use of a coolant. It is known that during cutting operations, the coolant forms a thin film layer at the tool-chip interface and decreases the friction, at the same time making the chip removal easier and decreasing the temperatures at the cutting area, ${ }^{29}$ thus delaying the wear of the cutting tool, compared to dry cutting. It was seen that the effective wear type of the $U$ and TiAlN/TiN-coated tools was the outer-corner wear (Figures 7a and 7b), while with the CT and CTT tools it was the flank wear (Figures 7c and 7d). Furthermore, it was observed that with the CT and CTT tools, the wear at the outer corner did not form as rapidly as with the untreated tool, but instead it followed a more uniform feed along the cutting edges. This was thought to be the result of the improvement in the wear resistance of the cutting tool provided with the cryogenic treatment.

During the drilling of the Ti-6Al-4V alloy, a tool-life curve was prepared to determine the effects of dry and wet cutting conditions on the tool life (Figure 8). From the curve, it can be seen that wet cutting conditions provided a significant increase in the tool life in comparison with the dry cutting conditions. As the thermal properties of Ti-6Al-4V are poor, the use of cutting fluids (or coolants) is very important to improve the tool life ${ }^{3}$. The highest tool life obtained under dry cutting conditions was $2.7 \mathrm{~min}$, while this value reached 19.9 min under wet cutting conditions. At this stage, the importance of using a coolant in the drilling of the Ti-6Al-4V alloy was once more confirmed. Under dry cutting conditions, the CT, CTT and TiAlN/TiN-coated tools exhibited life increases of $(25,50$ and 68$) \%$ compared to the $U$ tool. These values were $(76,87$ and 112$) \%$ in the case of wet cutting conditions. It is believed that cryogenic treatment and cryogenic treatment + tempering have important roles in reducing the size of carbide particles, providing a uniform carbide distribution, transforming the retained austenite to martensite and increasing the hardness and wear resistance of cutting tools. The tool wear experiments confirmed this as well.

The CTT tools provided an increase in the tool life of $20 \%$ under dry cutting conditions and $7 \%$ under wet cutting conditions in comparison with the CT tools. The TiAlN/TiN-coated drills exhibited the best performance among the tested drills. It is thought that the TiAlN/TiN coating has a multi-layer structure and a lower friction coefficient and makes the chip flow more easily during the cutting; due to these properties it has an important influence on the increase in the tool life. Apart from that, its high hardness and lower friction coefficient, compared with the uncoated tool, affected the increase in the tool life. It is interesting to note that the TiAlN/TiNcoated tool had a longer tool life under wet cutting conditions. This was believed to be a result of the solid 

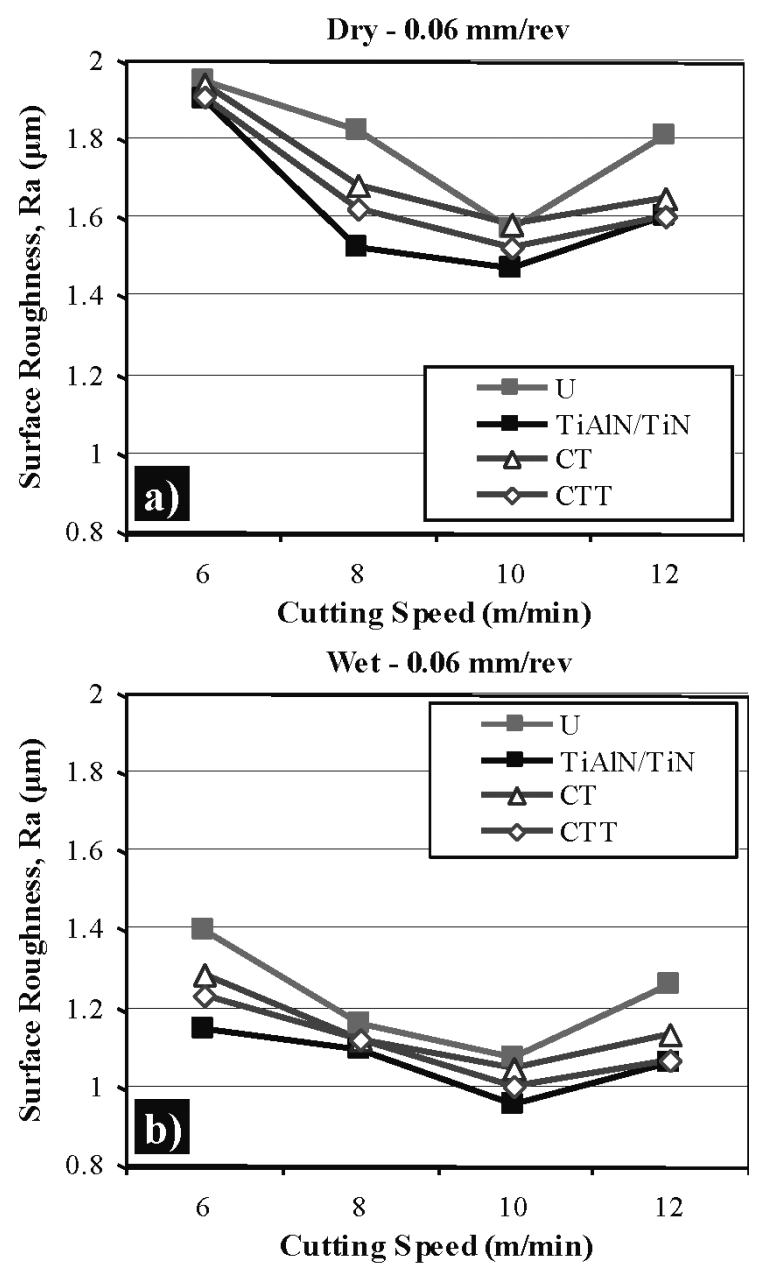

Figure 9: Different $R_{\mathrm{a}}$ values for the four tools, depending on cutting condition and cutting speed: a) dry, b) wet

Slika 9: Različne vrednosti $R_{\mathrm{a}}$ pri štirih orodjih v odvisnosti od razmer pri rezanju in hitrosti rezanja: a) suho, b) mokro

lubricating property of the coating acting together with the lubricating and cooling property of the coolant.

\subsection{Evaluation of the surface roughness}

Surface finish is also an important index of machinability or grindability because the performance and service life of the machined/ground components are often affected by their surface finish, the nature and extent of residual stresses and the presence of surface or subsurface microcracks, if any. This is particularly relevant when this component is to be used under dynamic loading or in conjugation with some other mating part(s). ${ }^{30}$ Figure 9 shows the differences in the surface roughness $\left(R_{\mathrm{a}}\right)$ among the four different tools, depending on the cutting speed and cutting conditions. For all four tools, with the increase in the cutting speed, the $R_{\mathrm{a}}$ values decreased up to the cutting speed of $10 \mathrm{~m} / \mathrm{min}$, but with further increases in the cutting speed, some increase in $R_{\mathrm{a}}$ was observed. It is thought that the decrease in $R_{\mathrm{a}}$ values with the increase in the cutting speed was due to the reduction in the BUE size with the temperature inc- rease at the tool-workpiece interface. ${ }^{31}$ Moreover, it is also believed that improved surface quality is influenced by the reduced friction resulting from the higher temperatures at the contact area at the tool-workpiece interface. ${ }^{32}$ The lowest $R_{\mathrm{a}}$ values among the four cutting tools were obtained for the holes drilled with the TiAlN/TiNcoated tools, followed by the CTT, CT and U tools, respectively. This sequence shows a parallelism with the one for the tool life. The average decreases in the $R_{\mathrm{a}}$ values of $(6.5,10.4$ and 15$) \%$ were obtained with the CT, CTT and TiAlN/TiN-coated tools compared to the U tools. With the TiAlN/TiN-coated tool, compared to the other tools, less BUE formation and wear led to an improved surface quality (Figures 5 to 7 ). It was seen that the combination of the cryogenic and tempering treatments was the second most effective procedure with respect to improving the surface quality due to the positive microstructural changes and the increase in the hardness and wear resistance, surpassed only by the improvement achieved with the TiAlN/TiN coating. Wet cutting conditions provided important improvements for all four tools regarding the trend toward reduced $R_{\mathrm{a}}$ values. Under dry cutting conditions, the $R_{\mathrm{a}}$ values were between $1.4 \mu \mathrm{m}$ and $1.94 \mu \mathrm{m}$ whereas under wet cutting conditions, the values ranged from $0.95 \mu \mathrm{m}$ to $1.4 \mu \mathrm{m}$. The main reasons for the difficult machinability of the Ti-6Al-4V alloy are its low heat-conductivity coefficient and high chemical reactiveness. The use of a coolant makes the chip removal easier, inhibits the heat formation in the cutting area, and decreases the BUE formation to a large extent. Taken altogether, these factors increase the surface quality in parallel with the increase in the tool life.

\section{CONCLUSIONS}

From the observed performance of the U, CT, CTT and TiAlN/TiN-coated M42 HSS drills in the machining of Ti-6Al-4V, the following conclusions were drawn:

- Cryogenic treatment significantly improved the wear resistance and tool life of M42 HSS drills under dry and wet conditions in the drilling of the Ti-6Al-4V alloy. Cryogenic treatment and tempering increased the performance of the cutting tools.

- By reducing the size of the carbide particles, cryogenic and tempering treatment enabled their uniform distribution and increased the concentration as well. Furthermore, the treatment had an important influence on the transformation of the retained austenite to martensite, a process which contributes to the abrasive-wear resistance as a result of the increased hardness.

- The CT and CTT tools, unlike the U tools, exhibited a performance approaching that of the TiAlN/TiNcoated tools. It was seen that the use of a coolant also had a significant influence on the increase in the tool life and surface roughness. In dry cutting conditions, 
the CT, CTT and TiAlN/TiN-coated tools exhibited an increase of $(25,50$, and 68$) \%$ in the tool life, compared to the $\mathrm{U}$ tools. Under wet cutting conditions, these values were $(76,87$ and 112$) \%$. Under dry cutting conditions, the effective wear types were BUE and catastrophic failure, whereas under wet cutting conditions, flank wear and outer-corner wear were effective.

- The biggest advantage of cryogenic treatment compared to coatings is its cheapness and its influence on the whole piece of the material. In this study, the results that were obtained showed that cryogenic treatment, with some improvement, can serve as an alternative to coatings.

\section{Acknowledgments}

The authors wish to express their sincere thanks to the Gazi University Scientific Research Project Division for its financial support for Project No: 07/2010-38.

\section{REFERENCES}

${ }^{1}$ R. R. Boyer, An overview on the use of titanium in the aerospace industry, Mater. Sci. Eng. A, 213 (1996), 103-114, doi:10.1016/ 0921-5093(96)10233-1

${ }^{2}$ F. Nabhani, Machining of Aerospace Titanium Alloys, Robot. CIM-Int. Manuf., 17 (2001), 99-106, doi:10.1016/S0736-5845(00) 00042-9

${ }^{3}$ E. O. Ezugwu, Z. M. Wang, Titanium Alloys and Their Machinability - a Review, J. Mater. Process. Technol., 68 (1997), 262-274, doi:10.1016/S0924-0136(96)00030-1

${ }^{4}$ S. Sun, M. Brandt, M. S. Dargusch, Machining Ti-6Al-4V alloy with cryogenic compressed air cooling, International Journal of Machine Tools \& Manufacture, 50 (2010), 933-942, doi:10.1016/ j.ijmachtools.2010.08.003

${ }^{5}$ J. L. Cantero, M. M. Tardío, J. A. Canteli, M. Marcos, M. H Miguélez, Dry drilling of alloy Ti-6Al-4V, Int. J. Mach. Tools Manuf., 45 (2005), 1246-1255, doi:10.1016/j.ijmachtools.2005.01. 010

${ }^{6}$ J. K. Schueller, J. Tlusty, S. Smith, E. Leigh, Advanced Machining Techniques on Titanium Rotor Parts, American Helicopter Society, 56th Annual Forum, Virginia Beach, VA, 2000

${ }^{7}$ L. Zeng, T. R. Bieler, Effects of Working, Heat Treatment, and Aging on Microstructural Evolution and Crystallographic Texture of $\alpha^{\prime}, \alpha^{\prime \prime}$, $\alpha^{\prime \prime}$ and $\beta$ Phases in Ti-6Al-4V Wire, Mater. Sci. Eng. A, 392 (2005), 403-414, doi:10.1016/j.msea.2004.09.072

${ }^{8} \mathrm{H}$. Fujii, Strengthening of $\alpha+\beta$ titanium alloys by thermomechanical processing, Mater. Sci. Eng. A, 243 (1998), 103-108, doi:10.1016/ S0921-5093(97)00786-7

${ }^{9} \mathrm{~S}$. Y. Hong, Y. Ding, Cooling approaches and cutting temperatures in cryogenic machining of Ti-6Al-4V, Int. J. Mach. Tools. Manuf., 41 (2001), 1417-1437, doi:10.1016/S0890-6955(01)00026-8

${ }^{10}$ A. K. Nady, M. C. Gowrishanka, S. Paul, Some studies on highpressure cooling in turning of Ti-6Al-4V, Int. J. Mach. Tools. Manuf., 49 (2009), 182-198, doi:10.1016/j.ijmachtools.2008.08.008

${ }^{11}$ S. S. Gill, R. Singh, H. Singh, J. Singh, Wear behaviour of cryogenically treated tungsten carbide inserts under dry and wet turning conditions, Int. J. Mach. Tools. Manuf., 49 (2009), 256-260, doi:10.1016/j.ijmachtools.2008.11.001

${ }^{12}$ A. Bensely, A. Prabhakaran, D. Mohan Lal, G. Nagarajan, Enhancing the wear resistance of case carburized steel (En 353) by cryogenic treatment, Cryogenics, 45 (2006), 747-754, doi:10.1016/ j.cryogenics.2005.10.004
${ }^{13}$ F. J. Da Silva, D. D. Franco, A. R. Machado, E. O. Ezugwu, A. M. Souza Jr, Performance of Cryogenically Treated HSS Tools, Wear, 261 (2006), 674-685, doi:10.1016/j.wear.2006.01.017

${ }^{14}$ A. Molinari, M. Pellizzari, S. Gialanella, G. Straffelini, K. H. Stiasny, Effect of Deep Cryogenic Treatment on the Mechanical Properties of Tool Steels, J. Mater. Process. Tech., 118 (2001) 5, 350-355, doi:10.1016/S0924-0136(01)00973-6

${ }^{15}$ J. Y. Huang, Y. T. Zhu, X. Z. Liao, I. J. Beyerlein, M. A. Bourke, T. E. Mitchell, Microstructure of Cryogenic Treated M2 Tool Steel, Mater. Sci. Eng. A, 339 (2003), 241-244, doi:10.1016/S0921-5093 (02)00165-X

${ }^{16}$ V. Firouzdor, E. Nejati, F. Khomamizadeh, Effect of deep cryogenic treatment on wear resistance and tool life of M2 HSS drill, J. Mater. Process. Technol., 206 (2008), 467-472, doi:10.1016/j.jmatprotec. 2007.12.072

${ }^{17}$ F. Cajner, V. Leskovšek, D. Landek, H. Cajner, Effect of Deep-Cryogenic Treatment on High Speed Steel Properties, Mater. Manuf. Process., 24 (2009), 743-746, doi:10.1080/10426910902809743

${ }^{18}$ D. Mohan Lal, S. Renganarayanan, A. Kalanidhi, Cryogenic treatment to augment wear resistance of tool and die steels, Cryogenics, 41 (2001), 149-155, doi:10.1016/S0011-2275(01)00065-0

${ }^{19}$ P. T. Schroeder, Widening interest in twist drill, Modern Mach. Shop, 71 (1998) 4, 106-113

${ }^{20}$ S. Sharif, E. A. Rahim, Performance of coated- and uncoated-carbide tools when drilling titanium alloy-Ti-6A14V, Journal of Materials Processing Technology, 185 (2007), 72-76, doi:10.1016/j.jmatprotec. 2006.03.142

${ }^{21}$ ASTM E 975-84, Standard Practice for X-Ray Determination of Retained Austenite in Steel with Near Random Crystallographic Orientation, ASTM, 1989

${ }^{22}$ S. Gimenez, I. Iturriza, Microstructural characterisation of PM M35MHV as a function of the processing route, Journal of Materials Processing Technology, 143-144 (2003), 555-560, doi:10.1016/ S0924-0136(03)00359-5

${ }^{23}$ J. Jeleńkowski, A. Ciski, T. Babul, Effect of deep cryogenic treatment on substructure of HS6-5-2 high speed steel, Journal of Achievements in Materials and Manufacturing Engineering, 43 (2010) 1, 80-87

${ }^{24}$ S. Zhirafar, A. Rezaeian, M. Pugh, Effect of cryogenic treatment on the mechanical properties of 4340 steel, J. Mater. Process. Technol., 186 (2007), 298-303, doi:10.1016/j.jmatprotec.2006.12.046

${ }^{25}$ Y. Dong, X. Lin, H. Xiao, Deep cryogenic treatment of high-speed steel and its mechanism, Heat Treatment of Metals, 3 (1998), 55-59

${ }^{26}$ A. Çiçek, T. Kıvak, İ. Uygur, E. Ekici, Y. Turgut, Performance of cryogenically treated M35 HSS drills in drilling of austenitic stainless steels, Journal of Advanced Manufacturing Technology, 60 (2012) 1-4, 65-73, doi:10.1007/s00170-011-3616-8

${ }^{27}$ I. Uygur, Microstructure and wear properties of AISI $1038 \mathrm{H}$ steel weldments, Lubr. Tribol. Ind., 58 (2006), 303-311, doi:10.1108/ 00368790610691383

${ }^{28}$ L. N. López de Lacalle, J. Pérez, J. I. Llorente, J. A. Sánchez, Advanced cutting conditions for the milling of aeronautical alloys, Journal of Materials Processing Technology, 100 (2000), 1-11, doi:10.1016/S0924-0136(99)00372-6

${ }^{29}$ S. Palanisamy, S. D. McDonald, M. S. Dargusch, Effects of coolant pressure on chip formation while turning Ti6A14V alloy, Int. J. Mach. Tools. Manuf., 49 (2009), 739-743, doi:10.1016/ j.ijmachtools.2009.02.010

${ }^{30}$ N. R. Dhar, M. Kamruzzaman, M. Ahmed, Effect of minimum quantity lubrication (MQL) on tool wear and surface roughness in turning AISI-4340 steel, J. Mater. Process. Technol., 172 (2006), 299-304, doi:10.1016/j.jmatprotec.2005.09.022

${ }^{31} \mathrm{C}$. Ibrahim, Machining of austenitic stainless steels using CVD multi-layer coated cemented carbide tools, Tribol. Int., 39 (2006), 565-569, doi:10.1016/j.triboint.2005.05.005

${ }^{32}$ E. M. Trent, Metal cutting, Butterworths Press, London 1989, 1-171 